\title{
Factors influencing job satisfaction among dentists during the new normal of the COVID-19 pandemic in Indonesia: A structural equation modeling approach
}

\author{
Yogi Tri Prasetyo ${ }^{\mathrm{a}, *}$, Titis Maulanti ${ }^{\mathrm{b}, \mathrm{c}, *}$, Satria Fadil Persada ${ }^{\mathrm{d}}$, Anak Agung Ngurah Perwira Redi ${ }^{\mathrm{e}}$, \\ Michael Nayat Young ${ }^{\mathrm{a}}$ and John Francis T. Diaz ${ }^{\mathrm{f}}$ \\ ${ }^{a}$ School of Industrial Engineering and Engineering Management, Mapúa University, Manila, Philippines \\ ${ }^{\mathrm{b}}$ Faculty of Dentistry, Universitas Indonesia, Jakarta, Indonesia \\ ${ }^{\mathrm{c}}$ Faculty of Public Health, Universitas Airlangga, Campus C, Mulyorejo, Surabaya, Indonesia \\ ${ }^{\mathrm{d}}$ Department of Business Management, Institut Teknologi Sepuluh November, Kampus ITS Sukolilo, Surabaya, \\ Indonesia \\ ${ }^{\mathrm{e}}$ Industrial Engineering Department, BINUS Graduate Program - Master of Industrial Engineering, \\ Bina Nusantara University, Jakarta, Indonesia \\ ${ }^{\mathrm{f}}$ Department of Finance and Management, Asian Institute of Management. Paseo de Roxas, Legazpi Village, \\ Makati, Metro Manila, Philippines
}

Received 22 March 2021

Accepted 21 June 2021

\begin{abstract}
.
BACKGROUND: Dentistry is one of the highest risk occupations that face COVID-19, especially in countries that are severely affected by the pandemic, such as Indonesia.

OBJECTIVE: The purpose of the study was to determine factors influencing job satisfaction among dentists during the new normal of COVID-19 pandemic in Indonesia by utilizing the Structural Equation Modeling (SEM) approach.

METHODS: A total of 310 Indonesian dentists voluntary completed an online questionnaire, which contained 58 questions. Several latent variables such as perceived severity of COVID-19, staff cooperation and management commitment, personal protective equipment, job stress, working hours, income, and overall job satisfaction were analyzed simultaneously.

RESULTS: SEM revealed perceived severity of COVID-19 had significant effects on job stress $(\beta: 0.394, p=0.025)$ and the utilization of personal protective equipment $(\beta: 0.757, p=0.001)$. Subsequently, job stress $(\beta:-0.286, p=0.001)$, working hours $(\beta: 0.278, p=0.018)$, income $(\beta: 0.273, p=0.003)$, personal protective equipment $(\beta: 0.145, p=0.038)$, and staff cooperation $\&$ management commitment $(\beta: 0.091, p=0.002)$ were found to have significant effects on overall job satisfaction. In addition, management \& staff cooperation was found to have a significant association with job stress reduction $(\beta:-0.319, p=0.003)$ which subsequently led to higher satisfaction.
\end{abstract}

*Address for correspondence: Yogi Tri Prasetyo, School of Industrial Engineering and Engineering Management, Mapúa University, Manila, Philippines. 658 Muralla St., Intramuros, Manila 1002, Philippines. Titis Maulanti, Universitas Indonesia,
Jakarta, Indonesia. Salemba Raya IV, Central Jakarta, Jakarta 10430, Indonesia. Tel.: +63 282475000 local 6202; E-mails: ytprasetyo@mapua.edu.ph (Yogi Tri Prasetyo); titismaulanti 1009@gmail.com (Titis Maulanti). 
CONCLUSIONS: The current study is one of the first that analyzed job satisfaction among dentists in Indonesia during the global COVID-19 pandemic. The integrated latent variables can be applied and extended to evaluate job satisfaction among dentists during the COVID-19 pandemic in other countries. Finally, this study contributed as a theoretical foundation for policymakers to enhance the job satisfaction of dentists during the COVID-19 pandemic.

Keywords: Dental macroergonomics, dentist income, job stress, personal protective equipment, health policy

\section{Introduction}

Indonesia is one of the countries that was severely hit by the COVID-19 pandemic. As of June 14, 2021, the COVID-19 pandemic has affected 1,919,547 people, including 53,116 deaths despite 29,869,630 vaccine doses have been administered [1-4]. Ironically, Indonesia was reported as the country with the highest number of death cases of medical workers in Asia with a total of 317 medical doctors, 33 dentists, and 235 nurses have reported deaths as of February 15,2021 while the number of active cases is continuously growing [5]. The type of transmission in Indonesia is categorized as community transmission, which is a larger outbreak of local transmission [6].

Due to the possible transmission route of exposure to disease and the time interval close contact during activities, dentists are placed to be the highest risk profession who face coronavirus disease 2019 (COVID-19) [7-11]. As of September 22, 2020, a total of 115 dentists were infected in Indonesia. On August 3, 2020, World Health Organization (WHO) released the interim guidance of consideration for the provision of essential oral health services in the context of COVID-19 based on scientific findings. WHO advised to delay oral health care related to nonemergency cases such as check-ups, dental cleanings, and preventive care until COVID-19 transmission was reduced [12]. This situation is a challenge for dentists to perform daily practices.

Along with facing a pandemic situation like this, undergoing dental practice is influenced by the level of job satisfaction of dentists during a pandemic. Some studies showed that the dentist's job satisfaction or quality life can impact job performance in daily practices [13, 14]. Interestingly, Ayers et al. [15] mentioned that there was a significant difference in the level of job satisfaction of male and female dentists. However, despite the availability of many studies related to job satisfaction among dentists [14-29], a very limited study focuses on job satisfaction during the COVID-19 pandemic. Quadri et al. [30] only investigated the awareness of
COVID-19 among dentists in Saudi Arabia. Similarly, Nibali et al. also only investigated the perceived impact of COVID-19 on the periodontal practice in United Kingdom [31]. Several factors during the COVID-19 pandemic such as perceived severity of COVID-19 [32-36], the availability of personal protective equipment (PPE) [37-40], stress [41], and mental health [41, 42] related to COVID-19 may influence job satisfaction among dentist. So, further research is required particularly for enhancing job satisfaction among dentists during the COVID-19 pandemic.

In dental research or dental ergonomics that utilized questionnaires, most studies only applied either ANOVA [31] or regression analysis [28]. These methods require at least three or even more constructs including the mediating variable to test the relationships among constructs [43]. Furthermore, the causal relationships were mainly underexplored. An advanced statistical approach is required to derive the causal relationships between the multivariable and it can be achieved by utilizing structural equation modeling.

Structural equation modeling (SEM) is an advanced statistical method that combined between multiple linear regression and factor analysis simultaneously [43]. In dental research, this method has been utilized by Fenlon and Sherriff [44] to determine factors affecting patients' satisfaction with new complete dentures. In addition, Yamaga et al. [45] also utilized this method for investigating the relationship between oral condition, denture quality, chewing ability, satisfaction with dentures, and oral healthrelated quality of life (OHRQoL) in complete denture wearers. In public health research, this method also has been performed to evaluate the extended IMB model for exploring the factors influencing health behaviors during COVID-19 [46]. Thus, this method can also be applied in determining factors affecting job satisfaction during the COVID-19 pandemic.

The purpose of this study was to determine factors influencing job satisfaction among dentists during new normal of COVID-19 pandemic in Indonesia 


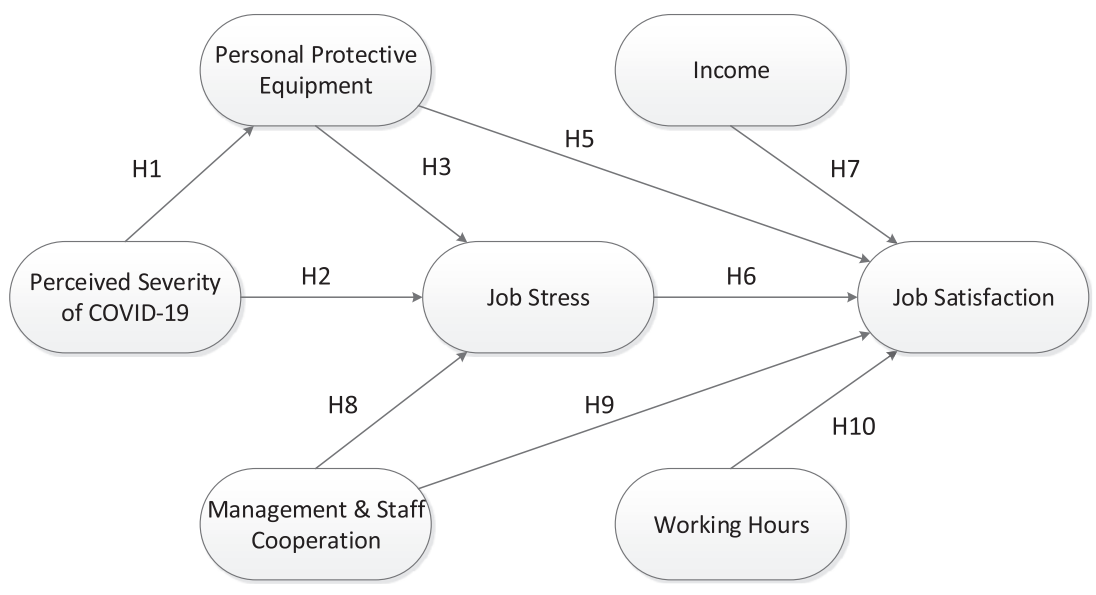

Fig. 1. The proposed model construct in the current study.

by utilizing Structural Equation Modeling (SEM) approach. Several latent variables such as perceived severity of COVID-19, staff cooperation \& management commitment, personal protective equipment, job stress [47, 48], working hours, income, and overall job satisfaction were analyzed simultaneously (Fig. 1). The current study is one of the first studies that analyzed job satisfaction among dentists during the global COVID-19 pandemic. The integrated latent variables can be applied and extended to evaluate job satisfaction among dentists during the COVID-19 pandemic in other countries. Finally, this study contributed as a theoretical foundation for policymakers and industry to enhance job satisfaction of dentist during the COVID-19 pandemic.

\section{Methods}

\subsection{Study participants}

A total of 310 dentists between 23 to 54 years old (mean: 27.57 , standard deviation: 4.54 ) voluntary participated in the current study (Table 1). They were registered in the Indonesian Medical Council and practiced before and/or during the COVID-19 pandemic. Among 310 dentists, a total of 242 (78.1\%) were reported still working during the COVID-19 pandemic.

Since the study was conducted during the new normal of the COVID-19 pandemic, an online questionnaire was distributed from August 10, 2020 to October 1, 2020 using convenience sampling method. It was distributed from one dentist to another dentist. Although this study was not required ethical approval,
Table 1

Socio-demographic characteristics $(n=310)$

\begin{tabular}{llcc}
\hline Characteristics & Category & $\mathrm{N}$ & $\%$ \\
\hline Gender & Male & 51 & 16.5 \\
& Female & 259 & 83.5 \\
Age & $15-24$ & 32 & 10.3 \\
& $25-34$ & 258 & 83.2 \\
& $35-44$ & 14 & 4.5 \\
Working Experience & $45-54$ & 6 & 1.9 \\
& $<5$ years & 269 & 86.8 \\
Still Working during COVID-19 & 5-10 years & 24 & 7.7 \\
pandemic? & $>10$ years & 17 & 5.5 \\
& Yes & 242 & 78.1 \\
& No & 68 & 21.9 \\
\hline
\end{tabular}

the data were collected anonymous, the confidentiality of the data was guaranteed, and the informed consent was obtained before the subject filled the questionnaire.

\subsection{Questionnaire}

A self-administered questionnaire was developed for this study. It was developed to determine factors influencing job satisfaction among Indonesian dentists during new normal of the COVID-19 pandemic in Indonesia (Table 2). The questionnaire consisted of 9 sections: (1) informed consents, (2) general characteristics of respondents (gender, age, years of practices, and practice during the COVID-19 pandemic or not), (3) perceived severity of COVID-19, (4) job stress, (5) personal protective equipment, (6) management of health services \& staff cooperation, (7) income, (8) working hours, and (9) overall dentist job satisfaction. All latent were measured by a 5-point Likert scale. 
Table 2

The constructs and measurement items

\begin{tabular}{|c|c|c|c|}
\hline Construct & Items & Measures & Supporting References \\
\hline \multirow[t]{9}{*}{$\begin{array}{l}\text { Perceived Severity of } \\
\text { COVID-19 }\end{array}$} & PS1 & I find COVID-19 is a serious disease & $\begin{array}{l}\text { Bashirian et al., } 2020^{32} \\
\text { Prasetyo et al., } 2020^{34}\end{array}$ \\
\hline & PS2 & I find COVID-19 can lead to death & Bashirian et al., $2020^{32}$ \\
\hline & & & Prasetyo et al., $2020^{34}$ \\
\hline & PS3 & I find COVID-19 is more severe than any other diseases & Bashirian et al., $2020^{32}$ \\
\hline & & & Prasetyo et al., $2020^{34}$ \\
\hline & PS4 & $\begin{array}{l}\text { I think the COVID-19 outbreak will continue at least until the } \\
\text { following } 3 \text { months }\end{array}$ & Cássaro \& Pires, $2020^{36}$ \\
\hline & PS5 & $\begin{array}{l}\text { I think the COVID- } 19 \text { outbreak in my country is more severe } \\
\text { than in other countries }\end{array}$ & Prasetyo et al., $2020^{34}$ \\
\hline & PS6 & I think it will be serious if I contract COVID-19 due to my work & Yildirim \& Güler, $2020^{33}$ \\
\hline & PS7 & I think dental practice is a high risk of COVID-19 infection & Rongo et al., $2020^{48}$ \\
\hline \multirow[t]{8}{*}{ Job Stress } & S1 & Dentistry is a very stressful profession & Cui et al., $2017^{22}$ \\
\hline & S2 & $\begin{array}{l}\text { Doing dentistry in this COVID-19 pandemic is very stressful } \\
\text { for me }\end{array}$ & Cui et al., ${ }^{22}$ \\
\hline & S3 & $\begin{array}{l}\text { Concern about the risk of contracting stressed me out during the } \\
\text { COVID-19 pandemic }\end{array}$ & Stefani et al., $2020^{39}$ \\
\hline & S4 & $\begin{array}{l}\text { The fear of professional risks that could affect my health } \\
\text { condition during the COVID-19 pandemic stressed me out }\end{array}$ & Tysiac-Mista \& Dziedzic, $2020^{38}$ \\
\hline & S5 & $\begin{array}{l}\text { The fear of the health risks my family members can experience } \\
\text { during the COVID-19 pandemic stresses me out }\end{array}$ & Tysiac-Mista \& Dziedzic, $2020^{38}$ \\
\hline & S6 & $\begin{array}{l}\text { I feel stressed by the news that my colleague has died from } \\
\text { COVID- } 19\end{array}$ & Grover et al., $2020^{42}$ \\
\hline & S7 & I am not confident treating a suspected case of COVID-19 & Stefani et al., $2020^{39}$ \\
\hline & S8 & $\begin{array}{l}\text { Overall, I feel stressed with my job being a dentist especially in } \\
\text { this COVID-19 pandemic }\end{array}$ & Roth et al., $2004{ }^{29}$ \\
\hline \multirow[t]{7}{*}{$\begin{array}{l}\text { Personal Protective } \\
\text { Equipment (PPE) }\end{array}$} & PPE1 & $\begin{array}{l}\text { I got the latest information about PPE that is better during the } \\
\text { COVID-19 pandemic }\end{array}$ & Houghton et al., $2020^{37}$ \\
\hline & PPE2 & $\begin{array}{l}\text { I work in a sufficiently equipped dental office during the } \\
\text { COVID-19 pandemic }\end{array}$ & Tysiac-Mista \& Dziedzic, $2020^{38}$ \\
\hline & PPE3 & $\begin{array}{l}\text { My job poses demands with having the right equipment and } \\
\text { resources during the COVID-19 pandemic }\end{array}$ & Mijiritsky et al., $2020^{47}$ \\
\hline & PPE4 & $\begin{array}{l}\text { The availability of PPE is a serious concern during the } \\
\text { COVID-19 pandemic }\end{array}$ & Houghton et al., $2020^{37}$ \\
\hline & PPE5 & $\begin{array}{l}\text { Additional training of donning and doffing PPE is a must for } \\
\text { health workers }\end{array}$ & Tabah et al., $2020^{40}$ \\
\hline & PPE6 & $\begin{array}{l}\text { Wearing PPE according to guidelines related to a dental } \\
\text { practice in a COVID-19 pandemic situation feels comfortable }\end{array}$ & Houghton et al., $2020^{37}$ \\
\hline & PPE7 & $\begin{array}{l}\text { Overall, wearing PPE makes me feel safe when the COVID-19 } \\
\text { pandemic is still ongoing }\end{array}$ & Houghton et al., $2020^{37}$ \\
\hline \multirow{8}{*}{$\begin{array}{l}\text { Management of } \\
\text { Health Services \& } \\
\text { Staff Cooperation }\end{array}$} & M1 & $\begin{array}{l}\text { The management instructed me to continue my dental practice } \\
\text { since the beginning of the COVID-19 outbreak }\end{array}$ & Tysiac-Mista \& Dziedzic, $2020^{38}$ \\
\hline & M2 & $\begin{array}{l}\text { I feel the management of health care support my work by } \\
\text { setting the facility based on the guideline of practices }\end{array}$ & Houghton et al., $2020^{37}$ \\
\hline & M3 & $\begin{array}{l}\text { The management gives the fair benefits package for the staffs } \\
\text { relating the situation of COVID-19 pandemic }\end{array}$ & Houghton et al., $2020^{37}$ \\
\hline & M4 & $\begin{array}{l}\text { The management ensure my safety and health during the } \\
\text { COVID-19 pandemic }\end{array}$ & Houghton et al., $2020^{37}$ \\
\hline & M5 & $\begin{array}{l}\text { The management gives me and other staffs training opportunity } \\
\text { of protection against the COVID-19 pandemic }\end{array}$ & Houghton et al., $2020^{37}$ \\
\hline & M6 & $\begin{array}{l}\text { I have the same value with management about the protection of } \\
\text { staffs in the COVID-19 pandemic }\end{array}$ & Houghton et al., $2020^{37}$ \\
\hline & M7 & $\begin{array}{l}\text { Overall, the managers of the health care services I work is } \\
\text { competent to manage the staffs in the COVID-19 pandemic } \\
\text { situation }\end{array}$ & Houghton et al., $2020^{37}$ \\
\hline & $\mathrm{SC} 1$ & $\begin{array}{l}\text { The number of staff in my practice is sufficient to serve patients } \\
\text { during the COVID-19 pandemic }\end{array}$ & Temesgen et al., $2018^{20}$ \\
\hline
\end{tabular}


Table 2

(Continued)

\begin{tabular}{|c|c|c|c|}
\hline Construct & Items & Measures & Supporting References \\
\hline & $\mathrm{SC} 2$ & $\begin{array}{l}\text { The quality of staff that I work with is responsive to the issue of } \\
\text { the COVID-19 pandemic }\end{array}$ & $\begin{array}{l}\text { Cui et al., } 2017^{22} \\
\text { Jeong et al., } 2006^{17}\end{array}$ \\
\hline & $\mathrm{SC} 3$ & $\begin{array}{l}\text { The staff I work with is excellent in serving patients during the } \\
\text { COVID-19 pandemic }\end{array}$ & $\begin{array}{l}\text { Cui et al., } 2017^{22} \\
\text { Jeong et al., } 2006^{17}\end{array}$ \\
\hline & $\mathrm{SC} 4$ & $\begin{array}{l}\text { All staff are working well together in dealing with the } \\
\text { COVID-19 pandemic }\end{array}$ & Cui et al., $2017^{22}$ \\
\hline & SC5 & $\begin{array}{l}\text { Good staff knowledge regarding COVID-19 supports teamwork } \\
\text { during the pandemic }\end{array}$ & Houghton et al., 202037 \\
\hline & SC6 & $\begin{array}{l}\text { All staff continue to respect each other in providing practical } \\
\text { services during the COVID-19 pandemic }\end{array}$ & Harris et al., $2009^{25}$ \\
\hline & $\mathrm{SC7}$ & $\begin{array}{l}\text { I feel motivated to create a nice atmosphere among staff in the } \\
\text { practice during the COVID-19 pandemic }\end{array}$ & Harris et al., $2009^{25}$ \\
\hline \multirow[t]{7}{*}{ Income } & I1 & $\begin{array}{l}\text { My income allows me to provide very well for my family since } \\
\text { the COVID-19 pandemic }\end{array}$ & $\begin{array}{l}\text { Cui et al., } 2017^{22} \\
\text { Jeong et al., } 2006^{17}\end{array}$ \\
\hline & I2 & $\begin{array}{l}\text { The income I receive from this job is much higher than I desire } \\
\text { due to the COVID-19 pandemic situation }\end{array}$ & $\begin{array}{l}\text { Cui et al., } 2017^{22} \\
\text { Jeong et al., } 2006^{17}\end{array}$ \\
\hline & I3 & $\begin{array}{l}\text { The income that I receive from my job is most satisfactory for } \\
\text { my needs although in the COVID-19 pandemic situation }\end{array}$ & $\begin{array}{l}\text { Cui et al., } 2017^{22} \\
\text { Jeong et al., } 2006^{17}\end{array}$ \\
\hline & I4 & $\begin{array}{l}\text { My income is comparable to other dentists during the } \\
\text { COVID-19 pandemic }\end{array}$ & $\begin{array}{l}\text { Cui et al., } 2017^{22} \\
\text { Jeong et al., } 2006^{17}\end{array}$ \\
\hline & I5 & $\begin{array}{l}\text { My income is comparable to other professions during the } \\
\text { COVID-19 pandemic }\end{array}$ & $\begin{array}{l}\text { Cui et al., } 2017^{22} \\
\text { Jeong et al., } 2006^{17}\end{array}$ \\
\hline & I6 & $\begin{array}{l}\text { My financial situation allowed me not to continue my practice } \\
\text { during the COVID-19 pandemic }\end{array}$ & Tysiac-Mista \& Dziedzic, $2020^{38}$ \\
\hline & I7 & $\begin{array}{l}\text { My financial situation allowed me to suspend my practice until } \\
\text { the number of COVID-19 cases started to decline }\end{array}$ & Tysiac-Mista \& Dziedzic, $2020^{38}$ \\
\hline \multirow[t]{7}{*}{ Working Hours } & WH1 & $\begin{array}{l}\text { The amount of work time available to me is sufficient to be able } \\
\text { to provide services to every patient during the COVID-19 } \\
\text { pandemic }\end{array}$ & Mijiritsky et al., 202047 \\
\hline & WH2 & I can do my job well in the COVID-19 pandemic situation & Mijiritsky et al., 202047 \\
\hline & WH3 & $\begin{array}{l}\text { I can flexibly schedule my job in the COVID-19 pandemic } \\
\text { situation }\end{array}$ & Sasso et al., $2015^{28}$ \\
\hline & WH4 & $\begin{array}{l}\text { I could have the opportunity to do other professions besides } \\
\text { dentistry during the COVID-19 pandemic }\end{array}$ & Sasso et al., $2015^{28}$ \\
\hline & WH5 & I can have a weekend off during the COVID-19 pandemic & Sasso et al., $2015^{28}$ \\
\hline & WH6 & $\begin{array}{l}\text { I can schedule my weekends off flexibly during the COVID- } 19 \\
\text { pandemic }\end{array}$ & Sasso et al., $2015^{28}$ \\
\hline & WH7 & $\begin{array}{l}\text { I have enough time for my personal life during the COVID-19 } \\
\text { pandemic }\end{array}$ & Sasso et al., $2015^{28}$ \\
\hline \multirow[t]{8}{*}{ Job Satisfaction } & JS1 & Dentistry fulfills my current career aspirations & $\begin{array}{l}\text { Cui et al., } 2017^{22} \\
\text { Jeong et al., } 2006^{17}\end{array}$ \\
\hline & JS2 & $\begin{array}{l}\text { I appear more satisfied with my job than I am even in the } \\
\text { COVID-19 pandemic situation }\end{array}$ & $\begin{array}{l}\text { Cui et al., } 2017^{22} \\
\text { Jeong et al., } 2006^{17}\end{array}$ \\
\hline & JS3 & $\begin{array}{l}\text { Dentistry is the place where I can make my best contribution in } \\
\text { this COVID-19 pandemic }\end{array}$ & $\begin{array}{l}\text { Cui et al., } 2017^{22} \\
\text { Jeong et al., } 2006^{17}\end{array}$ \\
\hline & JS4 & $\begin{array}{l}\text { I feel fortunate to be a dentist in the COVID- } 19 \text { pandemic } \\
\text { situation }\end{array}$ & $\begin{array}{l}\text { Fahim, } 2013^{16} \\
\text { Jeong et al., } 2006^{17}\end{array}$ \\
\hline & JS5 & $\begin{array}{l}\text { Facing this pandemic situation, I won't drop my job to do } \\
\text { something else }\end{array}$ & Jeong et al., $2006^{17}$ \\
\hline & JS6 & $\begin{array}{l}\text { I would make the same decision to go into dentistry again } \\
\text { although I have to face this COVID-19 pandemic situation }\end{array}$ & $\begin{array}{l}\text { Cui et al., } 2017^{22} \\
\text { Jeong et al., } 2006^{17}\end{array}$ \\
\hline & JS7 & $\begin{array}{l}\text { If my child were interested in dentistry, I would encourage } \\
\text { him/her to pursue a dental career although she/he has to face } \\
\text { this COVID-19 pandemic situation }\end{array}$ & $\begin{array}{l}\text { Cui et al., } 2017^{22} \\
\text { Jeong et al., } 2006^{17}\end{array}$ \\
\hline & JS8 & Overall, I am extremely satisfied with my career as a dentist & $\begin{array}{l}\text { Cui et al., } 2017^{22} \\
\text { Jeong et al., } 2006^{17}\end{array}$ \\
\hline
\end{tabular}




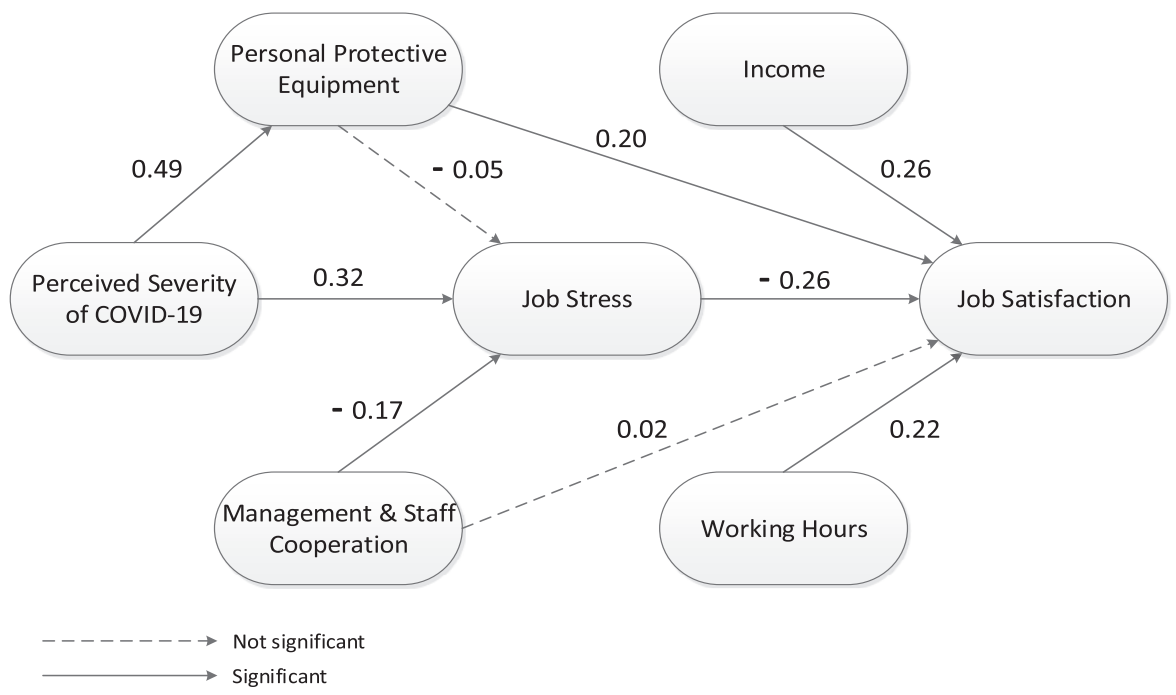

Fig. 2. The preliminary model.

\subsection{Structural equation modeling (SEM)}

SEM was computed by utilizing AMOS 24 with the Maximum Likelihood estimation approach. The Maximum Likelihood estimation approach was selected since it can derive the parameter estimates in a model by utilizing all information in the sets of equations simultaneously [49]. This approach is more advanced than the hierarchical regression since all the hypotheses construct can be analyzed simultaneously. The hypotheses construct had 7 latent variables including 4 exogenous latent variables (perceived severity of COVID-19, management \& staff cooperation, income, and working hours) and 3 endogenous latent variables (personal protective equipment, job stress, and job satisfaction).

Following some previous studies that utilized SEM approach [44, 45, 50, 51], 7 indexes were selected to access the model fit: (1) chi-square to degrees of freedom (CMIN/DF), (2) Goodness of Fit Index (GFI), (3) Adjusted Goodness of Fit Index (AGFI), (4) Root Mean Square Error of Approximation (RMSEA), (5) Incremental Fit Index (IFI), (6) Tucker Lewis Index (TLI), (7) Comparative Fit Index (CFI). A value lower than 2.00 for CMIN/DFis widely known as the minimum cut-off for a good model fit [43]. In addition, a value of higher than 0.80 is also a good cut-off for model fit for GFI and AGFI [52]. Similarly, a value of greater than 0.90 for IFI, CFI, TLI was also considered as a good fit [43]. Finally, a value of lower than 0.07 was considered as a good fit for RMSEA $[53,54]$.

\section{Results}

Figure 2 demonstrates the preliminary model of the current study. Based on this figure, there were two insignificant paths: PPE $\longrightarrow$ job stress $(\beta: 0.05$, $p=0.743)$, management \& staff cooperation $\longrightarrow$ job satisfaction $(\beta: 0.02, p=0.882)$. A final model was derived by eliminating these two paths. In addition, as suggested by Hair [43], the factor loading of each indicator should be higher than 0.5 to make sure the quality of the indicators. Based on Table 3, 17 out of 58 indicators were eliminated since the factor loadings were lower than 0.5 , including PS3, PS4, PS5, MS1, MS3, PPE5, PPE6, PPE7, S7, WH4, WH5, WH6, WH7, I6, I7, OS1, and OS2. In addition, following some of our previous studies that utilized SEM approach [34], some modification indices were also applied to enhance the model fit.

Figure 3 demonstrates the final SEM of factors influencing job satisfaction among dentist during new normal of COVID-19 pandemic. In addition, Tables 4 and 5 represent the model fit and the direct, indirect, total effects respectively. Based on Table 4, CMID/DF value was 1.739 , which was lower than the suggested cut-off of 2.00. The GFI and AGFI values were 0.843 and 0.816 respectively which were higher than the suggested cut-off of 0.8. Similarly, The IFI, TLI, and CFI values were higher than 0.9, indicating that the model is a good representation of the data. Finally, the RMSEA value was also lower than the suggested cut-off of 0.07 . 
Table 3

Descriptive statistic results

\begin{tabular}{|c|c|c|c|c|c|}
\hline \multirow[t]{2}{*}{ Factor } & \multirow[t]{2}{*}{ Item } & \multirow[t]{2}{*}{ Mean } & \multirow[t]{2}{*}{ StDev } & \multicolumn{2}{|c|}{ Factor Loading } \\
\hline & & & & $\begin{array}{l}\text { Initial } \\
\text { Model }\end{array}$ & $\begin{array}{l}\text { Final } \\
\text { Model }\end{array}$ \\
\hline \multirow[t]{7}{*}{ Perceived Severity of COVID-19 } & PS1 & 4.82 & 0.498 & 0.662 & 0.605 \\
\hline & PS2 & 4.80 & 0.499 & 0.675 & 0.613 \\
\hline & PS3 & 3.76 & 0.885 & 0.420 & - \\
\hline & PS4 & 4.59 & 0.636 & 0.380 & - \\
\hline & PS5 & 4.21 & 0.864 & 0.295 & - \\
\hline & PS6 & 4.78 & 0.514 & 0.726 & 0.525 \\
\hline & PS7 & 4.77 & 0.542 & 0.740 & 0.583 \\
\hline \multirow{14}{*}{$\begin{array}{l}\text { Management of Health Services } \\
\text { \& Staff Cooperation }\end{array}$} & MS1 & 2.97 & 1.238 & -0.026 & - \\
\hline & MS2 & 4.04 & 0.961 & 0.545 & 0.565 \\
\hline & MS3 & 3.08 & 1.273 & 0.495 & - \\
\hline & MS4 & 3.58 & 1.126 & 0.566 & 0.557 \\
\hline & MS5 & 3.24 & 1.254 & 0.451 & - \\
\hline & MS6 & 3.71 & 1.054 & 0.574 & 0.549 \\
\hline & MS7 & 3.60 & 0.983 & 0.581 & 0.565 \\
\hline & SC1 & 3.79 & 0.953 & 0.616 & 0.678 \\
\hline & $\mathrm{SC} 2$ & 3.90 & 0.887 & 0.819 & 0.844 \\
\hline & $\mathrm{SC} 3$ & 3.97 & 0.812 & 0.838 & 0.856 \\
\hline & SC4 & 4.03 & 0.788 & 0.872 & 0.914 \\
\hline & SC5 & 4.16 & 0.776 & 0.695 & 0.640 \\
\hline & SC6 & 4.29 & 0.716 & 0.745 & 0.693 \\
\hline & SC7 & 4.39 & 0.687 & 0.555 & 0.538 \\
\hline \multirow{7}{*}{$\begin{array}{l}\text { Personal Protective Equipment } \\
\text { (PPE) }\end{array}$} & PPE1 & 4.35 & 0.739 & 0.556 & 0.581 \\
\hline & PPE2 & 3.82 & 1.04 & 0.500 & 0.633 \\
\hline & PPE3 & 4.65 & 0.602 & 0.671 & 0.644 \\
\hline & PPE4 & 4.78 & 0.512 & 0.614 & 0.655 \\
\hline & PPE5 & 4.80 & 0.510 & 0.452 & - \\
\hline & PPE6 & 3.31 & 1.383 & 0.300 & - \\
\hline & PPE7 & 4.36 & 0.859 & 0.495 & - \\
\hline \multirow[t]{8}{*}{ Stress } & $\mathrm{S} 1$ & 3.13 & 1.277 & 0.570 & 0.555 \\
\hline & $\mathrm{S} 2$ & 3.51 & 1.151 & 0.820 & 0.801 \\
\hline & S3 & 3.79 & 1.100 & 0.875 & 0.870 \\
\hline & S4 & 3.57 & 1.094 & 0.913 & 0.911 \\
\hline & S5 & 3.89 & 1.054 & 0.871 & 0.865 \\
\hline & S6 & 3.91 & 1.025 & 0.770 & 0.773 \\
\hline & S7 & 4.14 & 1.005 & 0.414 & - \\
\hline & S8 & 3.53 & 1.151 & 0.834 & 0.835 \\
\hline \multirow[t]{7}{*}{ Working Hours } & WH1 & 3.76 & 0.838 & 0.729 & 0.740 \\
\hline & WH2 & 3.37 & 1.061 & 0.733 & 0.761 \\
\hline & WH3 & 3.71 & 1.024 & 0.739 & 0.749 \\
\hline & WH4 & 3.35 & 1.096 & 0.229 & - \\
\hline & WH5 & 3.78 & 1.103 & 0.290 & - \\
\hline & WH6 & 3.51 & 1.190 & 0.252 & - \\
\hline & WH7 & 4.08 & 0.992 & 0.263 & - \\
\hline \multirow[t]{7}{*}{ Income } & I1 & 3.06 & 1.09697 & 0.769 & 0.776 \\
\hline & I 2 & 2.17 & 1.00901 & 0.774 & 0.785 \\
\hline & $\mathrm{I} 3$ & 2.59 & 1.07208 & 0.897 & 0.921 \\
\hline & I4 & 2.65 & 0.94625 & 0.736 & 0.686 \\
\hline & I5 & 2.49 & 0.99752 & 0.699 & 0.638 \\
\hline & I6 & 2.62 & 1.11053 & 0.221 & - \\
\hline & I7 & 2.75 & 1.16775 & 0.192 & - \\
\hline \multirow{8}{*}{ Overall Satisfaction } & OS1 & 4.10 & 0.83743 & 0.498 & - \\
\hline & OS2 & 3.56 & 0.89286 & 0.441 & - \\
\hline & OS3 & 3.32 & 1.04547 & 0.685 & 0.656 \\
\hline & OS4 & 2.93 & 1.11375 & 0.690 & 0.670 \\
\hline & OS5 & 3.46 & 1.02889 & 0.773 & 0.749 \\
\hline & OS6 & 3.76 & 0.96350 & 0.745 & 0.712 \\
\hline & OS7 & 3.11 & 1.24671 & 0.548 & 0.511 \\
\hline & OS8 & 3.75 & 0.97438 & 0.707 & 0.695 \\
\hline
\end{tabular}




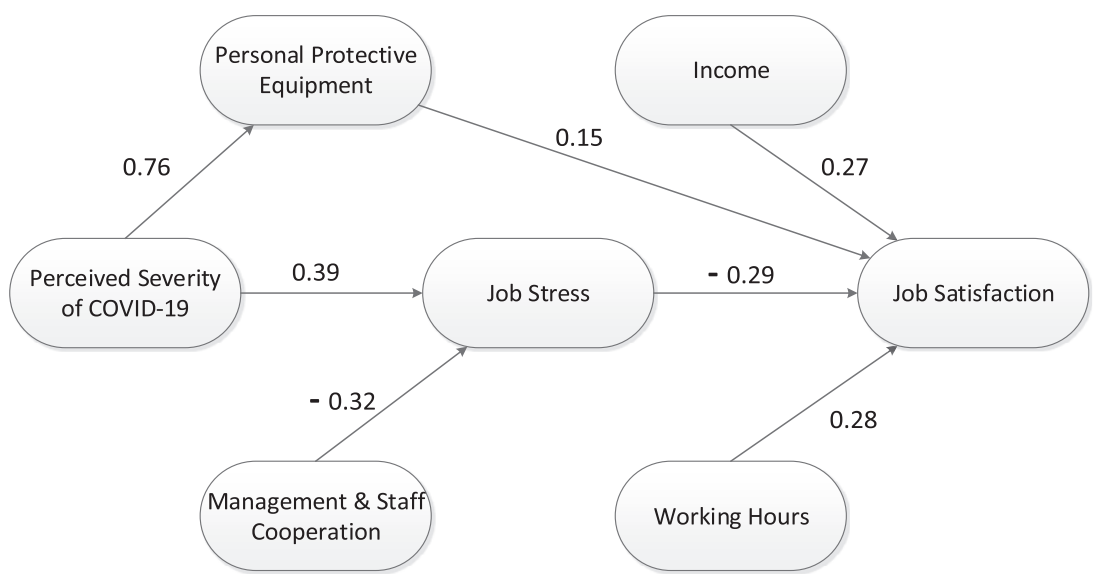

Fig. 3. The final SEM of factors influencing job satisfaction among dentist during new normal of COVID-19 pandemic.

\begin{tabular}{|c|c|c|c|c|}
\hline \multirow[t]{2}{*}{ Goodness of fit measures of the CFA } & \multicolumn{2}{|c|}{$\begin{array}{l}\text { Parameter } \\
\text { Estimates }\end{array}$} & \multirow[t]{2}{*}{$\begin{array}{l}\text { Suggested } \\
\text { cut-off }\end{array}$} & \multirow[t]{2}{*}{ Recommended by } \\
\hline & Initial & Final & & \\
\hline \multicolumn{5}{|l|}{ Absolute Fit Indices } \\
\hline CMIN/DF & 2.840 & 1.739 & $<2.00$ & Hair $(2010)^{43}$ \\
\hline Goodness of Fit Index (GFI) & 0.648 & 0.843 & $>0.80$ & Gefen et al., $(2000)^{52}$ \\
\hline Adjusted Goodness of Fit Index (AGFI) & 0.619 & 0.816 & $>0.80$ & Gefen et al., $(2000)^{52}$ \\
\hline Root Mean Square Error of Approximation (RMSEA) & 0.077 & 0.049 & $<0.07$ & Steiger., $(2007)^{53}$ \\
\hline \multicolumn{5}{|l|}{ Incremental Fit Indices } \\
\hline Incremental Fit Index (IFI) & 0.692 & 0.928 & $>0.90$ & Hair $(2010)^{43}$ \\
\hline Tucker Lewis Index (TLI) & 0.675 & 0.919 & $>0.90$ & Hair $(2010)^{43}$ \\
\hline Comparative Fit Index (CFI) & 0.690 & 0.928 & $>0.90$ & Hair $(2010)^{43}$ \\
\hline
\end{tabular}

Table 5

Direct, Indirect, and Total Effects

\begin{tabular}{llcccccc}
\hline No & Variables & Direct effect & $P$ value & Indirect effect & $P$ value & Total effect & $P$ value \\
\hline 1 & PS $\longrightarrow$ PPE & 0.757 & 0.001 & - & - & 0.757 & 0.001 \\
2 & PS $\longrightarrow$ S & 0.394 & 0.025 & - & - & 0.394 & 0.025 \\
3 & PS $\longrightarrow$ OS & - & - & -0.003 & 0.856 & -0.003 & 0.856 \\
4 & PPE $\longrightarrow$ OS & 0.145 & 0.038 & - & - & 0.145 & 0.038 \\
5 & MSC $\longrightarrow$ S & -0.319 & 0.003 & - & - & -0.319 & 0.003 \\
6 & MSC $\longrightarrow$ OS & - & - & 0.091 & 0.002 & 0.091 & 0.002 \\
7 & $\mathrm{~S} \longrightarrow$ OS & -0.286 & 0.001 & - & - & -0.286 & 0.001 \\
8 & $\mathrm{I} \longrightarrow$ OS & 0.273 & 0.003 & - & - & 0.273 & 0.003 \\
9 & WH $\longrightarrow$ OS & 0.278 & 0.018 & - & - & 0.278 & 0.018 \\
\hline
\end{tabular}

\section{Discussion}

According to SEM results, the perceived severity of COVID-19 among dentists had a significant effect on PPE $(\beta: 0.757, p=0.001)$ and job stress $(\beta: 0.394, p=0.025)$. A study conducted by Wahed et al. [35] found that risk perceptions of COVID19 were high due to the fear of transmitting the disease not only to them but also to their family. New guideline of COVID-19 prevention was announced to dentists, especially PPE procedure, due to high possibility transmission in dental practices [12]. This guideline also forced dentists to perform additional cleaning as stated by Houghton et al. [37]. Moreover, as supported by Tysiac-Mista et al. [38], this study suggests the coordination of health services related 
to the COVID-19 pandemic regarding the availability of PPE should be done when dentists performed their daily practices.

Regarding job stress, our study was in line with Martina et al. [48] that showed dentists considered their job as a high risk to them and their families. Thus, most dentists were scared to return the daily practices. Performing daily practices was a source of anxiety among dentists during large-scale social restriction of the COVID-19 pandemic [48]. Grover et al. [42] explained in their study that research should be focused on the impact of the COVID-19 pandemic among health workers' mental health. Furthermore, mental health professionals should emphasize that mental health goes hand in hand with physical health in this situation [42].

PPE is a widely discussed issue since this COVID19 pandemic has begun. The current study showed that PPE in the COVID-19 pandemic had an insignificant effect on job stress. However, Houghton et al. [37] mentioned that a lack of PPE, uncomfortable to use PPE, and feeling isolated and frightened by patients might become a serious concern for dentists. Tysiac-Mista et al. [38] also showed that a lack of PPE led to an overwhelming feeling of fear and anxiety among dental professionals. Moreover, using PPE tends to feel extreme exhaustion as explained by Turkoglu et al. [40].

The current study showed that job stress, working hours, income, and PPE were the main factors influence job satisfaction among dentists during new normal of the COVID-19 pandemic. Based on the SEM results, working hours $(\beta: 0.278, p=0.018)$, income $(\beta: 0.273, p=0.003)$, and PPE $(\beta: 0.145$, $p=0.038$ ) had significant positive effects on job satisfaction whereas job stress had a significant negative effect on job satisfaction $(\beta:-0.286, p=0.001)$. It could be interpreted that adjusting the working hours, income, PPE, and controlling the possible factors that affect stress during this COVID-19 pandemic should be done by the stakeholder for improvement of job satisfaction among dentists.

Interestingly, this study showed that income found to be one of the most significant factors in job satisfaction. This result was similar to several studies $[19,21-23,29]$ that showed income as a significant determinant of job satisfaction. According to Sasso et al. [28], dentists working in a large group setting are more satisfied with income and benefit than the dentist in solo practice. Benefit packages received by the dentists in a large group setting may impact their job satisfaction level [18].
SEM indicated that working hours significantly affect job satisfaction among dentists during new normal of the COVID-19 pandemic. This finding was supported by K. Goetz et al. [23] that working hours are one of the significant factors that affect overall job satisfaction among dentists. In line with this study, Luzzi and Spencer [14] also stated the flexible working hours of dentists may improve their job satisfaction. Slightly different from the existing study explained before, Al-Buainain et al. [24] found that the possibility to take an opportunity for parttime work besides daily practices affects the least job satisfaction among dentists.

PPE is the job satisfaction factor that has been found by the current study among Indonesian dentists during new normal of the COVID-19 pandemic. As explained by Zhang et al. [41], the importance of physical protection led to access to PPE become job satisfaction factors among health workers in Iran during the COVID-19 pandemic. Our study had completed the previous studies [54-58] by providing an overview of job satisfaction among Indonesian dentists that were affected by the PPE factor.

Regarding the job stress, this study showed a significant negative effect on job satisfaction. This result was similar to a study conducted by Roth et al. [29] and Cui et al. [22]. Moreover, Purine et al. [26] and Ab-Murat et al. [59] explained that dentists experience different kind of mental health impairments such as nervousness, physical burnout [58], anxiety, depression, sleeplessness, lack of self-esteem, and loneliness in their daily practices [26, 59]. This finding showed that stress and other mental health impairments threaten the mental health of dentists in their daily practices that may affect their job satisfaction. We suggest that preventive measures should be taken to reduce stress-causing factors for dentists during the COVID-19 pandemic.

Finally, regarding the management and staff cooperation of the health services factor, our study found this factor had a low significant indirect effect on job satisfaction ( $\beta: 0.091, p=0.002)$. Meanwhile, this factor had a significant negative direct effect to job stress $(\beta:-0.319, p=0.003)$. Although this finding differs from Roth et al. [29] and Sasso et al. [28], it could be interpreted that the stakeholder should pay attention to the management and staff cooperation of health services, so that it improves job satisfaction among dentist by reducing the job stress factor among dentists during new normal of COVID-19 pandemic [60]. 
Despite the high novelty and substantial contribution of the study, we would like to acknowledge several limitations about the current study's findings. First, our study assumed that the dentists were under homogenous institutions, in fact, dentists can work either in the hospital, clinic, or even in a small public health center. Future research to examine the effect of the institutions to the overall satisfaction would be a good research topic. Second, the respondents were not under the same province or city. Different provinces or cities could lead to a different level of perceived severity of COVID-19. In Indonesia, several provinces are under the green zone which means that the local transmission is less severe. Last but not the least, the current study selected six main factors as the main contributing factors to job satisfaction. In fact, there are several more factors that can influence the job satisfaction among dentists such as relationships with patients, the government supports, and even the existence of health insurance [61, 62]. Future research that incorporates these latent variables in the SEM would be a very promising research topic.

\section{Conclusion}

COVID-19 is a global crisis in 2020 [61]. In Indonesia, a total of 117 dentists were infected by COVID-19 as of September 29, 2020. Ironically, 33 dentists were passed away due to COVID-19 as of February 15, 2021 [5] and the numbers could be higher since Indonesia is one of the countries that seriously hit by COVID-19 pandemic.

The purpose of the study was to determine factors influencing job satisfaction among Dentist during new normal of COVID-19 pandemic in Indonesia by utilizing Structural Equation Modeling (SEM) approach. Several latent variables such as perceived severity of COVID-19, staff cooperation \& management commitment, personal protective equipment, stress, working hours, income, and overall satisfaction were analyzed simultaneously. A total of 310 dentists from Indonesia were voluntary filled an online questionnaire, which contained 58 questions. SEM indicated that perceived severity of COVID-19 had significant effects on job stress $(\beta: 0.394, p=0.025)$ and personal protective equipment $(\beta: 0.757, p=0.001)$. Subsequently, working hours $(\beta: 0.278, p=0.018)$, income $(\beta: 0.273$, $p=0.003)$, and PPE $(\beta: 0.145, p=0.038)$ had significant positive effects on job satisfaction whereas job stress had a significant negative effect on job satisfaction $(\beta:-0.286, p=0.001)$. In addition, management \& staff cooperation was found to have a significant association with job stress reduction ( $\beta:-0.319, p=0.003)$ which subsequently led to higher satisfaction. Interestingly, working hours and income were found to have the highest effect on overall satisfaction indicating that the policymakers should concern more on these two factors in order to enhance the job satisfaction among dentists in Indonesia.

The current study is one of the first studies that analyzed the job satisfaction among dentist during the global COVID-19 pandemic in Indonesia. The integrated latent variables can be applied and extended to evaluate the job satisfaction among dentists during the COVID-19 pandemic in other countries. Finally, this study contributed as a theoretical foundation for policymakers to enhance the job satisfaction of dentists during the COVID-19 pandemic.

\section{Acknowledgments}

The second author, Titis Maulanti DDS, would like to thank Indonesia Endowment Fund for Education (LPDP) for supporting the study. In addition, the authors would like to thank all dentists in Indonesia who voluntary participated in this study.

\section{Conflict of interest}

The authors declare that they have no known competing financial interests or personal relationships that could have appeared to influence the work reported in this paper.

\section{References}

[1] Indonesia: WHO Coronavirus Disease (COVID-19) Dashboard With Vaccination Data [Internet]. World Health Organization. World Health Organization; [cited 2021Jun14]. Available from: https://covid19.who.int/region/searo/coun try/id.

[2] Timeline: WHO's COVID-19 response [Internet]. World Health Organization. World Health Organization; [cited 2021Jun14]. Available from: https://www.who.int/emer gencies/diseases/novel-coronavirus-2019/interactivetimeline\# event- 0 .

[3] IHR Emergency Committee on Novel Coronavirus (2019-nCoV) [Internet]. World Health Organization. World Health Organization; [cited 2021Jun14]. Available from: https://www.who.int/director-general/speeches/detail/whodirector-general-s-statement-on-ihr-emergencycommittee-on-novel-coronavirus-(2019-ncov). 
[4] WHO Director-General's opening remarks at the media briefing on COVID-19 - 11 March 2020 [Internet]. World Health Organization. World Health Organization; [cited 2021Jun14]. Available from: https://www.who.int/ director-general/speeches/detail/who-director-general-sopening-remarks-at-the-media-briefing-on-covid-19-11march-2020.

[5] Indonesia [Internet]. Worldometer. [cited 2021Jun13]. Available from: https://www.worldometers.info/corona virus/country/indonesia/.

[6] Coronavirus disease (COVID-19) [Internet]. World Health Organization. World Health Organization; [cited 2021Jun13]. Available from: https://www.who.int/emergen cies/diseases/novel-coronavirus-2019?gclid=CjwKCAjw2 ZaGBhBoEiwA8pfP_ovvJBpUEDNgBbalIU2M_1MnHZij hgKbAPe523Xa_YYuZ86SxhUm0hoCKhkQAvD_BwE.

[7] Shereen MA, Khan S, Kazmi A, Bashir N, Siddique R. COVID-19 infection: Emergence, transmission, and characteristics of human coronaviruses. Journal of Advanced Research. 2020;24:91-8.

[8] Peng X, Xu X, Li Y, Cheng L, Zhou X, Ren B. Transmission routes of 2019-nCoV and controls in dental practice. International Journal of Oral Science. 2020;12(1).

[9] Contact Tracing for COVID-19 [Internet]. Centers for Disease Control and Prevention. Centers for Disease Control and Prevention; [cited 2021Jun13]. Available from: https://www.cdc.gov/coronavirus/2019-ncov/php/ contact-tracing/contact-tracing-plan/contact-tracing.html\#: $\sim:$ text=For $\% 20$ COVID-19\%2C\%20a\%20close,time $\% 20$ the $\% 20$ patient $\% 20$ is $\% 20$ isolated.

[10] Xu R, Cui B, Duan X, Zhang P, Zhou X, Yuan Q. Saliva: potential diagnostic value and transmission of 2019-nCoV. International Journal of Oral Science. 2020;12(1).

[11] Gamio L. The Workers Who Face the Greatest Coronavirus Risk [Internet]. The New York Times. The New York Times; 2020 [cited 2021Jun13]. Available from: https://www. nytimes.com/interactive/2020/03/15/business/economy/ coronavirus-worker-risk.html.

[12] Considerations for the provision of essential oral health services in the context of COVID-19 [Internet]. World Health Organization. World Health Organization; [cited 2021Jun13]. Available from: https://www.who.int/ publications/i/item/who-2019-nCoV-oral-health-2020.1.

[13] Balasubramanian M, Spencer AJ, Short SD, Watkins K, Chrisopoulos S, Brennan DS. Job satisfaction among 'migrant dentists' in Australia: implications for dentist migration and workforce policy. Australian Dental Journal. 2016;61(2):174-82.

[14] Luzzi L, Spencer AJ. Job satisfaction of the oral health labour force in Australia. Australian Dental Journal. 2010; 56(1):23-32.

[15] Ayers KMS, Thomson WM, Rich AM, Newton JT. Gender differences in dentists' working practices and job satisfaction. Journal of Dentistry. 2008;36(5):343-50.

[16] Fahim A. Predictors of job satisfaction among practicing dentists at hospitals in Suez Canal Area, Egypt. International Journal of Occupational Medicine and Environmental Health. 2013;26(1).

[17] Jeong S-H, Chung J-K, Choi Y-H, Sohn W, Song K-B. Factors related to job satisfaction among South Korean dentists. Community Dentistry and Oral Epidemiology. 2006;34(6):460-6.

[18] Merga H, Fufa T. Impacts of working environment and benefits packages on the health professionals' job satisfaction in selected public health facilities in eastern Ethiopia: using principal component analysis. BMC Health Services Research. 2019;19(1).

[19] Gedif G, Sisay Y, Alebel A, Belay YA. Level of job satisfaction and associated factors among health care professionals working at University of Gondar Referral Hospital, Northwest Ethiopia: a cross-sectional study. BMC Research Notes. 2018;11(1).

[20] Temesgen K, Aycheh MW, Leshargie CT. Job satisfaction and associated factors among health professionals working at Western Amhara Region, Ethiopia. Health and Quality of Life Outcomes. 2018;16(1).

[21] Alhajj MN, Omar R, Khader Y, Celebić A, El Tantawi M, Folayan MO, et al. Happiness among dentists: a multi-scale, multi-national study from 21 countries. International Dental Journal. 2020;70(5):328-39.

[22] Cui X, Dunning D, An N. Satisfaction among early and midcareer dentists in a metropolitan dental hospital in China. Journal of Healthcare Leadership. 2017;9:35-45.

[23] Goetz K, Campbell SM, Broge B, Dörfer CE, Brodowski $\mathrm{M}$, Szecsenyi J. The impact of intrinsic and extrinsic factors on the job satisfaction of dentists. Community Dentistry and Oral Epidemiology. 2012;40(5):474-80.

[24] Al-Buainain FS, Alzarouni AA, Alshamsi HA, Arab AH, Bader F, Awad M. Job Satisfaction of U.A.E. Dental Practitioners. European Journal of Dentistry. 2019;13(03):354-60.

[25] Harris R, Burnside G, Ashcroft A, Grieveson B. Job satisfaction of dental practitioners before and after a change in incentives and governance: a longitudinal study. British Dental Journal. 2009;207(2).

[26] Purine A, Aleksejuniene J, Petrauskiene J, Balciuniene I, Janulyte V. Self-perceived Mental Health and Job Satisfaction among Lithuanian Dentists. Industrial Health. 2008;46(3):247-52.

[27] Hamasha AA-H, Alturki A, Alghofaili N, Alhomaied A, Alsanee F, Aljaghwani F, et al. Predictors and level of job satisfaction among the dental workforce in national guard health affairs. Journal of International Society of Preventive and Community Dentistry. 2019;9(1):89.

[28] Lo Sasso AT, Starkel RL, Warren MN, Guay AH, Vujicic M. Practice settings and dentists' job satisfaction. The Journal of the American Dental Association. 2015;146(8):600-9.

[29] Roth SF, Heo G, Varnhagen C, Major PW. The relationship between occupational stress and job satisfaction in orthodontics. American Journal of Orthodontics and Dentofacial Orthopedics. 2004;126(1):106-9.

[30] Quadri MFA, Jafer MA, Alqahtani AS, Al mutahar SAB, Odabi NI, Daghriri AA, et al. Novel corona virus disease (COVID-19) awareness among the dental interns, dental auxiliaries and dental specialists in Saudi Arabia: A nationwide study. Journal of Infection and Public Health. 2020;13(6):856-64.

[31] Nibali L, Ide M, Ng D, Buontempo Z, Clayton Y, Asimakopoulou K. The perceived impact of Covid-19 on periodontal practice in the United Kingdom: A questionnaire study. Journal of Dentistry. 2020;102:103481.

[32] Bashirian S, Jenabi E, Khazaei S, Barati M, KarimiShahanjarini A, Zareian S, et al. Factors associated with preventive behaviours of COVID-19 among hospital staff in Iran in 2020: an application of the Protection Motivation Theory. Journal of Hospital Infection. 2020;105(3):430-3.

[33] Yildirim M, Güler A. COVID-19 severity, self-efficacy, knowledge, preventive behaviors, and mental health in Turkey. Death Studies. 2020;1-8.

[34] Prasetyo YT, Castillo AM, Salonga LJ, Sia JA, Seneta JA. Factors affecting perceived effectiveness of COVID-19 
prevention measures among Filipinos during Enhanced Community Quarantine in Luzon, Philippines: Integrating Protection Motivation Theory and extended Theory of Planned Behavior. International Journal of Infectious Diseases. 2020;99:312-23.

[35] Abdel Wahed WY, Hefzy EM, Ahmed MI, Hamed NS. Assessment of Knowledge, Attitudes, and Perception of Health Care Workers Regarding COVID-19, A CrossSectional Study from Egypt. Journal of Community Health. 2020;45(6):1242-51.

[36] Cássaro FAM, Pires LF. Can we predict the occurrence of COVID-19 cases? Considerations using a simple model of growth. Science of The Total Environment. 2020;728: 138834.

[37] Houghton C, Meskell P, Delaney H, Smalle M, Glenton C, Booth A, et al. Barriers and facilitators to healthcare workers' adherence with infection prevention and control (IPC) guidelines for respiratory infectious diseases: a rapid qualitative evidence synthesis. Cochrane Database of Systematic Reviews. 2020;2020(8).

[38] Tysiąc-Miśta M, Dziedzic A. The Attitudes and Professional Approaches of Dental Practitioners during the COVID-19 Outbreak in Poland: A Cross-Sectional Survey. International Journal of Environmental Research and Public Health. 2020;17(13):4703.

[39] De Stefani A, Bruno G, Mutinelli S, Gracco A. COVID19 Outbreak Perception in Italian Dentists. International Journal of Environmental Research and Public Health. 2020;17(11):3867.

[40] Turkoglu M. Personal Protective Equipment Use for COVID-19 Patients in Intensive Care Unit. Journal of Critical and Intensive Care. 2020;

[41] Zhang SX, Liu J, Afshar Jahanshahi A, Nawaser K, Yousefi A, Li J, et al. At the height of the storm: Healthcare staff's health conditions and job satisfaction and their associated predictors during the epidemic peak of COVID-19. Brain, Behavior, and Immunity. 2020;87:144-6.

[42] Grover S, Dua D, Sahoo S, Mehra A, Nehra R, Chakrabarti S. Why all COVID-19 hospitals should have mental health professionals: The importance of mental health in a worldwide crisis! Asian Journal of Psychiatry. 2020;51: 102147.

[43] Hair JF. Multivariate data analysis: a global perspective. Upper Saddle River, N.J: Pearson Education; 2010.

[44] Fenlon MR, Sherriff M. An investigation of factors influencing patients' satisfaction with new complete dentures using structural equation modelling. Journal of Dentistry. 2008;36(6):427-34.

[45] Yamaga E, Sato Y, Minakuchi S. A structural equation model relating oral condition, denture quality, chewing ability, satisfaction, and oral health-related quality of life in complete denture wearers. Journal of Dentistry. 2013;41(8): 710-7.

[46] Luo Y, Yao L, Zhou L, Yuan F, Zhong X. Factors influencing health behaviours during the coronavirus disease 2019 outbreak in China: an extended information-motivationbehaviour skills model. Public Health. 2020;185:298-305.

[47] Mijiritsky E, Hamama-Raz Y, Liu F, Datarkar AN, Mangani L, Caplan J, et al. Subjective Overload and Psychological Distress among Dentists during COVID-19. International Journal of Environmental Research and Public Health. 2020;17(14):5074.
[48] Martina S, Amato A, Rongo R, Caggiano M, Amato M. The Perception of COVID-19 among Italian Dentists: An Orthodontic Point of View. International Journal of Environmental Research and Public Health. 2020;17(12):4384.

[49] Schumacker RE. Interaction and Nonlinear Effects in Structural Equation Modeling. Routledge; 2017.

[50] Ashoori F, Karimi M, Mokarami H, Seif M. Using health belief model to predict oral health behaviors in girl students: A structural equation modeling. Pediatric Dental Journal. 2020;30(1):24-32.

[51] Yamaga E, Sato Y, Soeda H, Minakuchi S. Structural equation modeling of the impact of mandibular ridge form and denture quality on oral health-related quality of life in complete denture wearers. Journal of Prosthodontic Research. 2019;63(3):293-8.

[52] Gefen D, Straub D, Boudreau M-C. Structural Equation Modeling and Regression: Guidelines for Research Practice. Communications of the Association for Information Systems. 2000;4.

[53] Steiger JH. Understanding the limitations of global fit assessment in structural equation modeling. Personality and Individual Differences. 2007;42(5):893-8.

[54] Ayim Gyekye S. Workers' Perceptions of Workplace Safety and Job Satisfaction. International Journal of Occupational Safety and Ergonomics. 2005;11(3):291-302.

[55] Satuf C, Monteiro S, Pereira H, Esgalhado G, Marina Afonso R, Loureiro M. The protective effect of job satisfaction in health, happiness, well-being and selfesteem. International Journal of Occupational Safety and Ergonomics. 2016;24(2):181-9.

[56] Fang Y-Y, Huang C-Y, Hsu M-C. Effectiveness of a physical activity program on weight, physical fitness, occupational stress, job satisfaction and quality of life of overweight employees in high-tech industries: a randomized controlled study. International Journal of Occupational Safety and Ergonomics. 2018;25(4):621-9.

[57] Kunecka D, Skowron $Ł$. The model of professional satisfaction of nursing staff in Poland - brief communication. International Journal of Occupational Safety and Ergonomics. 2018;25(4):646-9.

[58] Vitharana VH, Chinda T. Structural equation modelling of lower back pain due to whole-body vibration exposure in the construction industry. International Journal of Occupational Safety and Ergonomics. 2017;25(2):257-67.

[59] Ab-Murat N, Mason L, Kadir RA, Yusoff N. Self-perceived mental well-being amongst Malaysian dentists. International Journal of Occupational Safety and Ergonomics. 2017;24(2):233-9.

[60] Ünal Ö. During COVID-19, which is more effective in work accident prevention behavior of healthcare professionals: Safety awareness or fatalism perception? Work. 2020;67(4):783-90.

[61] Garzillo EM, Monaco MG, Spacone A, Inglese E, Lamberti M, Pompei D. SARS-CoV-2 emergency in the workplace: are companies ready to protect their workers? A crosssectional survey. International Journal of Occupational Safety and Ergonomics. 2020;1-8.

[62] Sarfaraz S, Ahmed N, Abbasi MS, Sajjad B, Vohra F, AlHamdan RS, et al. Self-perceived competency of the medical faculty for E-Teaching during the COVID-19 pandemic. Work. 2020;67(4):791-8. 